\title{
IMMIGRATION AND REDISTRIBUTION IN A GLOBAL ERA
}

\author{
Stuart Soroka \\ McGill University \\ stuart.soroka@mcgill.ca \\ Keith Banting \\ Queen's University \\ bantingk@qsilver.queensu.ca \\ Richard Johnston \\ University of British Columbia \\ rjohnstn@interchange.ubc.ca
}

Prepared for delivery at the Annual meeting of the Canadian Political Science Association, Dalhousie University, Halifax NS, May29-June 12003.

This research is made possible by the "Equality, Security, and Community" Major Collaborative Research Initiative, Jon Kesselman, Principal Investigator. Financial support comes from the Social Sciences and Humanities Research Council of Canada and our respective universities. We are grateful for the encouragement of Michael Wallerstein, Samuel Bowles, and Pranab Bardhan. None of these institutions or individuals is responsible for any errors of fact or interpretation. 


\section{IMMIGRATION AND REDISTRIBUTION IN A GLOBAL ERA}

Debates about the impact of globalization on the redistributive capacities of the state have paid remarkably little attention to the most human dimension of the global era, the movement of millions of people around the globe. There are intense debates about whether globalization constrains the room to manoeuvre available to nation states, or tilts the domestic political balance between traditional supporters and opponents of the welfare state. But students of globalization have largely ignored the impact of immigration on the politics of redistribution.

This intellectual divide presumably reflects the fact that immigration has not been part of the international process of economic liberalization in recent decades. Whereas multilateral agreements have facilitated trade and capital flows around the world, the movement of people remains regulated by national laws. Immigration was deliberately left beyond the ambit of trade agreements, and immigration policy continues to reflect the resilience of nation states and domestic politics (Joppke 1999). ${ }^{1}$ Moreover, national legislation has not become more open in the last 20 years; if anything, politics have driven in the opposite direction here. As Rodrik has noted, "the liberalization of trade and capital flows has benefited greatly from the push of political forces. The same forces have been conspicuous by their absence in the case of international labour movements" (Rodrik 2002: 341).

Nevertheless, waves of global economic integration do seem to be linked historically with mass movements of people..$^{2}$ The late $19^{\text {th }}$ and early $20^{\text {th }}$ centuries, a period of rapid growth in international trade and foreign investment, witnessed a great migration that brought over 25 million people to the United States alone. The current wave of globalization is also accompanied by large-scale migration, and the rate of movement was accelerating in the closing years of the century. The United Nations estimates that as many as 150 million people live outside the country of their birth - approximately 2.3 percent of the earth's population. Although this percentage has not changed significantly since the 1965, there have been important shifts in the nature of the flows in different regions of the world. Migrants have increased as a proportion of the total population throughout Europe, North America, Australia and New Zealand. By 1998, migrants represented over 20 percent of the population in Australia, New Zealand and Switzerland, 18 percent in Canada, almost 12 percent in the United States, and close to 10 percent in France, the Netherlands and Sweden. Equally important, the sources of immigration have shifted, with larger proportions of immigrants to northern countries coming from peripheral regions-such as Turkey in the case of Europe and Mexico in the case of the US - and from developing countries of the south. These changes have increased the ethnic, linguistic and religious diversity of the populations of advanced welfare states, and made multiculturalism a defining feature of the contemporary era.

Immigration has the potential to raise powerful challenges to the political legitimacy of the welfare state. Immigration can unsettle historic conceptions of community, which define those

${ }^{1}$ There is a debate about the extent to which national immigration policies are constrained by international human rights regimes. Whatever side of the debate one takes, however, it is clear that such constraints as do exist are less stringent than those in the world of trade and finance. See Joppke 1999 and Soysal 1994.

2 For an argument that if money, goods and ideas flow effortlessly around the globe, people will have to follow eventually, see Sassen 1998. 
who are "us," recognized members of existing networks of rights and obligations, and those who are "strangers" or "others" whose needs seem less compelling. According to many commentators, the growing presence of newcomers, especially ethnically distinct newcomers, may erode the sense of social solidarity on which welfare states are constructed.

This paper examines the relationship between immigration and the welfare state, arguing that there is indeed a link between increasing levels of migration and decreasing social welfare expenditures. The chapter begins with a description of existing research, and a review of the various linkages that may exist between social spending and immigration. We then explore the links between these two variables in advanced industrial democracies since 1965 with multivariate analyses at various time scales. These analyses suggest that increasing migration is one way in which globalization may adversely affect social welfare programs.

\section{EXISTING RESEARCH}

As noted above, the literature on globalization has yet to come to grips with immigration. Analysts have focused on whether globalization limits the capacity of countries to build and preserve distinctive social contracts that reflect domestic politics and cultures. Although economic integration may not trigger a race to the very bottom, many worry that it creates pressures for convergence towards the more modest level of social protection in the trading system, such as is characteristic of the United States. ${ }^{3}$ Others have asked whether globalization weakens social solidarity within countries, eroding the foundations on which the welfare state was built. Over a decade ago, Robert Reich argued that globalization and technological change have increased not only the income gap but also the political gap between highly skilled professionals and unskilled workers, as Reich's symbolic analysts retreat physically and politically into gated communities (Reich 1991). Others have argued that economic restructuring has shifted the domestic political balance between capital and labour. But this literature has not asked whether immigration patterns are also straining social cohesion or disrupting the political coalitions that built the welfare state.

The same gap appears in the literature on the welfare state. The first generation of this research highlighted the role of class structures and alliances, the strength of organized labour and role of social democratic politics in the rise of the welfare state (Stephens 1979, Korpi 1983, EspingAnderson 1985). More recent analyses of differences in the levels of social spending have broadened the range of factors to include the level of economic development, the openness of the economy, the size of the elderly population, the relative strength of organized labour, the historical dominance of parties of the left and right, and in more recent studies, the structure of political institutions. In contrast, immigration and ethnic diversity of populations receive little attention. ${ }^{4}$ For example, four recent book-length studies by leading scholars in the field are all silent on these social changes (Hicks 1999; Huber and Stephens 2001; Swank 2002; EspingAndersen 2002).

3 For recent discussions, see Garrett 1998, Hall and Soskice 2001, and Kitschelt, Lange, Marks and Stephens 1999.

4 One early exception was Stephens 1979, which noted that ethnic and linguistic diversity was strongly and negatively correlated with the level of labour organization, which in turn was strongly related to social spending. However, this early lead did not figure in Stephen's own later work (see Huber and Stephens 2001). 
Fortunately, other researchers have not been so reticent. The large literature on immigration has explored the interactions between immigration and social programs. Economists in particular have asked whether generous social programs represent a welfare magnet, part of the attractive pull for people from low-income countries. In the case of the U.S., Borjas argues thatwelfare programs reduce out-migration among immigrants who fail in the US labour market, increasing migrants as a proportion of the total population (Borjas 1999: 114-15). In similar terms, a recent European study concluded that, while the effect is moderate in quantitative terms, generous social benefits in countries like Denmark and the Netherlands seem to attract migrants disproportionately likely to be dependent on welfare (Boeri et al 2002: chapter 3). Economists have also asked whether migrants rely more heavily on social assistance programs than natives. This was not the case in the 1960s. But recent migrants from low-income countries tend to have lower educational and skill levels relative to the native population, and to face greater problems in the labour market. Although the evidence suggests that the long-term net fiscal impact is small, most studies conclude that in the short-term-which is probably more important politicallyimmigrants in Europe and the US rely more heavily than natives on social assistance programs, especially in "gateway" cities and regions. ${ }^{5}$

Political resentment about such welfare dependency contributed to a backlash in a number of jurisdictions, most famously in California during the 1990s, and governments have often responded with policy changes that deny or delay eligibility for welfare programs to immigrants. In the United States, the largest financial savings from the welfare reforms introduced by the 1966 Personal Responsibility and Work Opportunity Reconciliation Act resulted from restrictions on immigrant eligibility for social benefits, including Food Stamps, Supplementary Security Income, Medicaid, and public assistance. A similar pattern of requiring immigrants to establish longer periods of residency before qualifying for a variety of means-tested programs has emerged in a number of other countries, including Australia and the United Kingdom (Banting 1999: 120121). The Danes have recently moved in the same direction (Economist 2003).

The politics of immigration and the welfare state is also charged by the multicultural nature of contemporary migration flows. Immigration and ethnic diversity are analytically distinct phenomena. Not all immigration increases the ethnic diversity of host countries; indeed, for twothirds of the twentieth century, immigration policies in most welfare states were carefully designed to avoid such an outcome. And not all ethnic diversity is the result of recent immigration; in many cases, ethno-linguistic differences predates the formation of the states which now contain them, or reflect population movements centuries old, as in the case of African Americans. Nevertheless, in the last 30 years, immigration has been a source of growing ethnic and racial diversity in most western countries

As a result, the politics of the welfare state is increasingly haunted by a difficult question: is there is a deep tension between ethnic diversity and strong public support for redistribution? Research in a surprisingly diverse set of fields suggests that the answer may be yes. For example, development economists at the World Bank and elsewhere increasingly point to the debilitating

${ }^{5}$ See OECD 1997; Borjas 1994, 1999; Boeri et al 2002. This evidence has sparked proposals in both Europe and the US for reforms to immigration policy to actively select more highly skilled immigrants, as is done in Canada where immigrants appear less dependent on social assistance than natives (Baker and Benjamin quoted in Borjas 1994, pp. 1703-04). 
consequences of ethnic rivalries and conflicts in explaining the weaker economic and social performance of a number of poorer countries, especially in Africa. While the main focus of this literature is on economic growth, findings also suggest that spending on private as opposed to public education tends to be higher in countries with more linguistic and religious diversity, and transfer payments tend to be lower in countries with high levels of ethnic diversity. ${ }^{6}$ Similar tensions are highlighted in studies of the developed world. Race has been a long-standing feature in studies of the politics of social policy in the United States. Numerous authors have told the story of the way in which the politics of race contributed to the fracturing of the New Deal coalition. In addition, recent studies have pointed to racial diversity in explaining why Americans "hate welfare" (Gilens 1999), why the United States did not develop a European-style welfare state (Alesina, Glaeser and Sacerdote 2001), and why there are significant differences in the level of social expenditures across cities and states within the country (Alesina, Baqir and Easterly 1997; Hero and Tolbert 1996; Plotnick and Winters 1985). In Europe, a study of European attitudes towards immigrants and their reliance on welfare concludes that opposition is driven less by economic and fiscal concerns than by racial intolerance (Boeri et al. 2002: chapter 5). And political scientists seeking to understand the strength of radical right-wing parties point to a potent cocktail of resentments against racially-distinct immigrants and social transfers to them leading one prominent scholar to worry about the basic political viability of a multicultural welfare state (Kitschelt 1995; but see also Swank and Betz forthcoming).

The same tension echoes in the political theory of nationalism, multiculturalism and the citizenship. In his analysis of nationalism, David Miller has argued that mutual trust facilitates support for social programs, that trust is aided by identification with fellow citizens, and that such identification is easier in ethnically and culturally homogeneous societies. By implication, more diverse societies will find support for social welfare less certain (Miller 1995: 90-99). ${ }^{7}$ A particularly intense debate centres on multiculturalism. Here the focus is not on the level of ethnic diversity per se, but on multiculturalism policies that provide public recognition, support, or accommodation of ethnic groups, their identities and their practices, whether in schools, in public rituals, or in public spending. The critics insist that multicultural policies erode the welfare state by diverting time, energy and money from the politics of redistribution to the politics of recognition, or by eroding trust and solidarity among marginal groups that would otherwise be natural allies, or by leading vulnerable groups to define their problems as a reflection of their ethnicity rather than economic barriers that confront other groups as well (Barry 2001; Gitlin 1995; Wolfe and Klausen 1997).

Such arguments do not go without challenge. Canada represents an interesting test case for such arguments, characterized as it is by the powerful combination of a historic division between English and French-speaking communities, the presence of aboriginal peoples, and one of the very highest immigration rates in the world. Moreover, Canada is widely seen as a leader among countries adopting strong multiculturalism policies. Notwithstanding this complexity, evidence from a national survey designed to plumb the relationships among ethnic diversity, levels of inter-

6 See, for example Easterly 2001a and 2001b; Easterly and Levine 1997; James 1987, 1993; Nettle 2000; and Grafton, Knowles and Owen 2002.

${ }^{7}$ See also Steinmo's suggestion that the recent Swedish pattern depends on the ethnically homogeneous nature of its population (Steinmo 2003: 44). Similar themes can be found in recent discussions about the nature of altruism and reciprocity in experimental economics (Bowles, Fong and Gintis 2001). 
personal trust, and support for social programs finds no evidence that ethnic diversity and multiculturalism erode support for the welfare state (Soroka, Johnston, and Banting 2002). A cross-national analysis of links between multiculturalism policies and social policies finds a similar lack of relationship. In general, countries that have adopted strong multiculturalism policies have not had greater difficulties in sustaining their welfare states over the last 25 years than other countries (Banting and Kymlicka 2003). This does not preclude the possibility that such tensions do exist in particular places for particular groups of people, however.

Clearly, the debate about globalization and the redistributive state needs to be extended to incorporate the movement, not just of microchips and money, but of people, millions of people who represent the human face of a global era. Given the concern that globalization erodes the capacity of nation states to sustain ambitious social contracts, a key question is whether immigration affects political support for the welfare state? The causal pathway may be direct, in weakening the attitudinal base for welfare programs among the public. Or it may be indirect, in inducing a surge in support for parties of the "New Right". Support for these parties may be driven by anti-immigrant sentiment and not by antipathy to the welfare state. But the parties themselves commonly express such antipathy, so a New Right groundswell is likely to carry policy consequences beyond resistance to immigration.

A proper test of these propositions requires a fully specified model of demand for social spending. Immigration can affect welfare expenditure in quasi-automatic ways, some increasing proportionate outlays, others decreasing them. Immigration levels themselves can be affected by other factors in welfare supply and demand, and so simple bivariate tests are vulnerable to charges of spuriousness. A properly specified model will also give us some sense not just of whether immigration matters but of how much it matters, compared to other factors. It should also bring out divergence in effect between the short and long run.

The literature suggests a number of possible pathways or links between immigration and social spending:

A. Increased immigration is associated with increased social spending, at least in the short term:

1. In Europe and the United States, recent immigrants have lower levels of education and training, weaker economic performance, and heavier reliance on unemployment and social assistance benefits than both previous generations of immigrants and natives.

2. Immigrants tend to be younger on average than natives, altering the demographic profile of the country and raising expenditures on child-related programs, such as child benefits and education.

B. Increased Immigration leads to reduced social spending :

1. For the same reason, that immigrants tend to be younger than natives, immigration reduces the share of the population over 65 . To the extent that the welfare state is oriented more to the old than the young, immigration reduces demand for social services quasi-automatically, and this alone would create a negative relationship between immigration and social spending. This relationship would be causal, certainly not spurious, but in contrast to the effect in A.2., it is of little political interest. Its possibility alerts us to the need for a fully specified 
setup, however. Conceivably, over the full life-cycle the net demographic impact of immigration on the destination country's fiscal position is small and ambiguous.

2. Most critically, increasing proportions of "new" beneficiaries-who have not been contributors - may lead to a decline in general public support for redistributive policies, whatever the beneficiary group.

3. It could lead to pressures to reduce the eligibility of immigrants in particular for welfare. If immigrants come to dominate the traditional categories of welfare eligibility, this would reduce the system's overall transfer capacity, or limit growth in social expenditures. ${ }^{8}$

4. Over time, political resistance to high levels of immigration increases support for conservative political parties. In the European context, the vehicle for this protest tends to be radical right-wing parties. ${ }^{9}$ Voters supporting such parties may not intend any signal about the welfare state but find themselves inadvertently sending such a signal anyway.

Whatever the predicted direction of impact, all the foregoing place immigration in the causal driver's seat. Immigration levels themselves can also be the consequence of prior differences or changes in social spending:

C. High social spending may lead to increased immigration:

1. Generous social assistance programs represent a welfare magnet that increases immigration and/or reduces out-migration among migrants who fail in the labour market.

D. High social spending leads to reduced immigration:

1. Political reaction to high levels of immigration and immigrant dependency on welfare may also be to tighten immigration policy and reduce immigration levels rather than cut welfare benefits. Traditional supporters of the welfare state, such as labour unions, might prefer reduced economic migration to reduced welfare spending for natives.

This enumeration of competing and often contradictory causal pathways reinforces the need mentioned above for a fully specified model. Moreover, to the extent that social spending is driven by factors outside any nexus with immigration, control for these factors should help stabilize the estimation and allow immigration-related effects to emerge. Estimation needs to be

${ }^{8}$ The Canadian model is arguably a variant on this. Canadian immigration policy selects a relatively skilled immigration flow through a points system and by requiring sponsorship agreements for family reunification, such that sponsors guarantee that sponsored immigrants will remain off welfare for ten years.

${ }^{9}$ See Kitschelt (1997) for European cases. The Canadian Reform party (now the Alliance) that broke through in 1993 also exemplifies this kind of reaction. 
sensitive to lags and to time scale, to account for the just-enumerated divergence among predictions.

\section{Migration AND Social Spending: The BaSic PatTern}

Table 1 presents the data on social spending and immigration for all OECD countries for which data are available. Figure 1 presents the basic relationship between the two for the 1970-98 interval, a period of notable gains in overall international migration and striking changes in its sources. By "social spending" is meant total social welfare spending as a proportion of GDP, created by splicing together two OECD series: the 1980-2000 OECD Social Expenditures Database (SOCX), and 1960-1980 data from the appendix in OECD, Social expenditure, 19601990: Problems of growth and control (OECD 1985). By "immigration" is meant foreign-born migrant stock as a proportion of the total population. Yearly data are based on UN estimates for $1965,1975,1985,1990$, and 2000, with linear interpolation for intervening years. ${ }^{10}$ Migrant stock is only one of several possible indicators. Swank and Betz (forthcoming) use inflows of asylum seekers and refugees, for instance. This indicator may be suited to modelling right-wing party support, but represents an incomplete measure for our purposes. Others (e.g., Boeri 2002) have used measures of foreign nationals, also an incomplete measure as it is affected by naturalization rates, which vary greatly across countries. Total net migration is a readily available measure, but outflows can (and do) hide considerable inflows in certain countries. The ideal series for our purposes might be total gross migration, but the measure is available only for select OECD countries in certain years. Our indicator - change in migrant stock - captures more migrants than the asylum-seekers measure and should be unaffected by naturalization rates .

[Table 1 about here]

[Figure 1 about here]

Table 1 shows levels of spending and migrant stock for the countries in our sample in 1970 and 1998. These are the first and last years for which data are available for all countries, but these years also nicely capture the recent period of globalization. Without exception, immigrants claim a larger share of each country's population in 1998 than in 1970. Averaged across the whole set of countries, that share is roughly two-thirds again as large at the end as at the beginning. This cannot have produced a global reduction in social spending, however, as spending growth has been even more spectacular; typically a near doubling of its share of GDP. However, if no country has seen a decline in either indicator, cross-national variation in each is striking. So the question becomes whether the rate at which social spending increases is larger or smaller according to the magnitude of immigration.

At first cut, in Figure 1, the answer seems to be clearly yes. The figure plots percentage-point changes in the variables against each other. The largest increases in migrant stock are associated with the smallest increases in social welfare expenditures. The relationship does not appear to be linear, however. A quadratic fit represents the relationship in a simple and powerful way, as

${ }^{10}$ OECD data on migrant stock are available yearly from 1980, but only for some of the countries in our sample and in some cases only intermittently. UN and OECD definitions and sources are slightly different, so the two sets of data cannot be merged. We rely on the UN data because they are available more consistently, for a greater number of countries, and over a longer time period. 
further analysis will confirm. By the quadratic relationship in the graph, a country with an average net gain in foreign-born would devote about $1.5 \%$ less of GDP to social spending than it would have had it closed its borders. ${ }^{11}$

\section{MULTIVARIATE ESTIMATIONS}

Figure 1 establishes only a starting point, however, as it glosses over all the explanatory considerations and caveats mentioned earlier. Not least, it leaves completely open the direction of causation. A more rigorous test of the relationship will include variables capturing political, economic and demographic effects on social welfare expenditures, closely modelled on Huber and Stephens 2001, Swank 2002, and Hibbs 2002.

Four political variables merit consideration:

- Left party seats as a percentage of all seats in the governing coalition.

- Christian Democratic party seats as a percentage of all seats in the governing coalition.

- Right wing (RW) party votes as a percentage of all votes.

- Union density, union membership as a percentage of the employed labour force.

Both Huber and Stephens 2001 and Swank 2002 find that Left and Christian Democratic representation in government increase social welfare spending, hence our concentration on seats in the numerator and governing coalition - as opposed to the whole Parliament-seats in the denominator. Right wing parties (not Christian Democratic parties) are represented by their share in the overall system, not just in governing coalitions (which they rarely are invited to join), and by votes, not seats (to partly get around electoral system effects). The supposition is that impact from RW parties is through perceived electoral threat, not through conventional bargaining at cabinet tables (Kitschelt 1997). Inclusion of union density follows Hicks 1999, among others.

Economic and demographic variables are essentially "demand" variables positively linked to increases in social welfare expenditures:

- The percentage of the population below 16, anticipating that infants will increase health care and day care costs and that school-age children will increase education costs.

${ }^{11}$ A natural anxiety, however, is that the relationship is driven by the extreme cases, the US and the Netherlands. As it happens, the relationship is not merely dependent on one or the other of these countries. Dropping the US from the estimation weakens it hardly at all. Dropping the Netherlands, cuts the value of linear and quadratic coefficients by about $30 \%$ but leaves them significant by a one-tailed test. Cutting both countries does drive the relationship effectively to zero. The two hardly seem like an artifactual pair, however. Just about the only thing they have in common are changes in the variables of central interest. Another anxiety is Switzerland: it appears on the figure as a clear outlier, with the highest apparent growth in both migrant stock and social spending. The Swiss data are not useable, however, as the OECD changed its calculation of Swiss public social expenditure in 1990. Spending on occupational pensions and on health insurance were previously considered as private but are now classed as public. Moreover, post-1990 calculations appear to include both compulsory and voluntary spending on these two programs. For these reasons, we excluded Switzerland from the estimation. If Switzerland is included, however, the relationship evaporates. We are grateful to Giuliano Bonoli for advice on the Swiss case. 
- The population of the population over 64 , the most powerful single driver of social spending growth.

- Inflation (year over year change in CPI).

- Unemployment, a key source of short-term flux.

- The percent of females in the labour force, following Huber and Stephens (2001), a driver of child care costs.

In all estimations, social spending (as a dependent variable) and immigration are modelled as changes, the current value minus the preceding value. As Table 1 and Figure 1 show, levels of spending increased across all countries in our sample during this period, so it is the magnitude of the increase that matters. As it is spending change that we model, it seems appropriate that it be driven by change rather than level of migrant stock. Other variables are modelled as levels or changes according to the logic of the situation. Huber and Stephens 2001 suggest, for example, that the partisan composition of government has an effect on spending that is cumulative, requiring an extended period to manifest itself, while economic and demographic variables have more concurrent effects. The mix of change and level variables will reflect the time scale for the estimation.

Moreover, the time scale should be allowed to vary. There is an appealing directness to the 28year period in Figure 1, so we start with an estimation quite like the one implicit in the figure, and we elaborate on it. The number of variables quickly converges on the number of cases, however, and causal priority always remains a nagging issue in what can never get beyond being a crosssectional estimation. There follows, then, a more ambitious setup: time-series cross-sectional (TSCS) analyses of changes in social welfare spending from 1965 to 2000, using five- to one-year time periods. Successive re-estimations allow us to examine the period over which different variables have (or do not have) an effect on social spending.

\section{Cross-sectional analysis}

Results from the cross-sectional analyses of 1970-1998 changes are presented in Table 2. For these models, migrant stock and social spending are measured in 1970-1998 changes, while all other variables are measured as averages over this period. Model 1 examines the simple impact of 1970-98 percentage-point changes in migrant stock and the corresponding changes in social welfare expenditures. The only additional variable is the 1970 level of social spending, included to allow for the possibility that countries initially spending a great deal on social welfare will have less potential for increase than countries that spend comparatively less. Model 2 extends the analysis to all variables with potential impact except union density. The last indicator is missing for three of the eighteen countries, so we drop it to preserve degrees of freedom; it returns in the richer TSCS estimations below. This saturated estimation creates a baseline for comparison with the TSCS models. Model 3 in Table 2 presents the results of backward elimination of variables, such that only those that cross at least the 0.10 threshold for statistical significance remain. Each of Models 1 through 3 is estimated separately for linear and quadratic representations of growth in migrant stock.

Table 2 confirms the superiority of the quadratic model of immigration effects. The coefficient on the migration variable is always more stable in quadratic form and rather more variance is 
explained. ${ }^{12}$ Whatever the form of the migration indicator, its impact is utterly independent of the level of social spending in 1970, in the sense that migration coefficients in Table 1 are essentially identical to those implicit in Figure $1 .^{13}$ Impact from the 1970 spending level variable is negative, as expected, but insignificant.

[Table 2 about here]

The direct effect of immigration is largely impervious to control. The value of the coefficient hardly changes as additional variables come and go. The saturated model generates enough multicollinearity to expand the standard error on the immigration coefficient, taking it below the conventional significance threshold, but the trimmed estimation (Model 3) renders it even more stable and significant than in the baseline model. The impact remains as before: the typical migration experience lowers the predicted growth in welfare spending by 1.5 points, about $15 \%$ of the average expenditure change (10.1 percentage points) during the period.

Of the variables that remain, female labour force participation and the percentage over 64 dominate the impact from demography. Left seats in governing coalitions dominates among political factors. What all this means is that the impact of immigration is largely unmediated by variables that lie along the potential causal pathways outlined earlier. Immigration does affect the percentage over 64 (Table A2) and that percentage does affect welfare spending, but the effect of each on the ultimate dependent variable is independent of the effect of the other. Immigration growth is a factor in support for parties of the new Right (Table A2, again), but social spending seems unaffected by the threat posed by such parties.

\section{TSCS analysis}

Cross-sectional estimations have the advantage of being relatively simple and surprisingly robust given the small number of observations. Restricting the estimation to 1970-1998 changes is not ideal, however. Effects may be masked or augmented by the long time period. The small number of observations restricts the deployment of potential explanatory and control variables. Accordingly, Tables 3 and 4 present results from time-series cross-sectional (TSCS) analyses. Following Beck and Katz (1995), analyses use panel-corrected standard errors (PCSEs). ${ }^{14}$ The sample size in the yearly TSCS analysis varies from 78 and 560, depending on temporal frequency, so we can afford to be more aggressive about explanatory variables. Some estimations include total union density, which was excluded from cross-sectional analyses. Estimations begin with 5-year intervals, where a yearly dataset is collapsed into 5-year periods beginning in 1965 and all variables represent their average value over the 5-year interval. Political variables are included as levels for each 5-year period; all other variables are included as changes from the last 5 -year period to the current one. For such variables entries are for $t-1$ rather than $t$, on the grounds that budgets for the current period are made in the previous period, so it should be the last

${ }^{12}$ The quartic form was also tested, proved to be slightly less powerful a curvilinear representation than the more accessible quadratic.

${ }^{13}$ For instance, the quadratic coefficient in Figure 1 is -0.742 . In Table 2 it is -0.724 .

${ }^{14}$ To check for any autocorrelation that might remain after differencing, all regressions were also replicated using a Prais-Winsten estimation accounting for first-order autoregressive processes. In all case, the estimated $\rho$, the coefficient indicating serial correlation in disturbances, is small and other results do not change. 
period's government that has an effect on this period's spending (see, e.g., Wlezien 1996; Wlezien and Soroka 2003). ${ }^{15}$ The model is then replicated using successively smaller intervals, culminating with a frequency of one year.

Table 3 bridges us to the baseline quadratic estimation in Table 2. In this simple setup, impact from immigration seems unaffected by the temporal frequency. ${ }^{16}$ By implication, a one-point change in migrant stock over 5 years should have roughly the same effect as a one-point change over one year. Relative to the cross-sectional estimation, however, its substantive significance seems reduced. In the yearly model, a one-point change in migrant stock is associated with a .023-point decrease in social-spending. In coefficients, this suggests that immigration has a shortterm impact only one-fifth to one-quarter as great as its cumulative impact. Put another way, however, the substantive significance of immigration is reduced even more: the average yearly change in migrant stock, +0.124 , predicts a 0.003 -point decrease in social spending change, less than one percent of the average yearly change in social spending $(+0.385)$.

\section{[Table 3 about here]}

As in the cross-sectional estimation, the direct impact of immigration shrinks only slightly, if at all, when other variables enter the fray in Table 4. The first five columns (Model 1) deploy the same countries as Table 2. The second five (Model 2) are of greater substantive interest, as they include the effect of union density (with three fewer countries, however). There is a hint in both models that the impact of immigration is slightly more mediated - its coefficient shrinks - the higher the frequency. The most likely mediating variable is the demography of age: the impact from the percentage under 16 grows as the estimation's temporal frequency increases.

\section{[Table 4 about here]}

Immigration is not the only variable to see its effect attenuate as we move from cross-sectional to TSCS setups. As foreshadowed by Huber and Stephens 2001, the effect of the partisan composition of government disappears almost entirely in the shorter-term TSCS models. Only in the 5- and 3-year models are left party seats significant, and then only with union density excluded (Model 1). As before, neither Christian Democratic seats in government nor right wing party votes in the electorate have any impact. ${ }^{17}$

The effect of economic and demographic "demand" variables increases in significance as the time period shortens, confirming that these variables have sizeable influence on social spending in the short term. Changes in the unemployment rate are consistently positive and significant; changes in the CPI are positive and usually significant. As in the 28-year model, the percentage of women

15 This is less clear when we are looking at longer intervals than one year, admittedly. Accordingly, these variables were tested at both $t$ and $t-1$.

16 The principal effect of increasing the frequency is to bring lagged spending into the realm of statistical significance, but only by shrinking standard errors through sheer multiplication of degrees of freedom.

17 Swank's and Betz' (forthcoming) finding that inflows of asylum seekers and refugees are positively associated with right wing party vote shares is echoed in our TSCS data set, in a regression (not reported here) of right wing vote share on changes in migrant stock, unemployment, inflation, and GDP per capita. 
in the labour force is positively associated with social spending. So too is union density, in line with previous work.

The varying effects of demographic variables across models deserve some explanation. First, the fact that population over 64 is no longer significant in the TSCS analyses should not be taken at face value. Lagged levels of welfare spending are highly correlated with lagged levels of population over 64. (Population over 64 is the variable that is most highly correlated with levels of welfare spending, in fact; see bivariate correlations in the appendix.) As a consequence, the effect of this population variable likely occurs in these models mainly over the long term via lagged levels of spending. Population under 16, on the other hand, was not significant in the 28year model but is consistently significant in the TSCS analyses. It appears as though this variable has a shorter- rather than longer-term impact. ${ }^{18}$

\section{DISCUSSION AND CONCLUSIONS}

International migration does seem to matter for the size of the welfare state. Although no welfare state has actually shrunk in the face of the accelerating international movement of people, its rate of growth is smaller the more open a society is to immigration. To the extent that spending growth is inescapable, mandated by the aging of populations in industrial societies, specific parts of the welfare states - especially the parts that redistribute from rich to poor or from the old to the young-may truly have shrunk in the face of migratory pressures. Whatever the details, the typical industrial society might spend 16 or $17 \%$ more than it now does on social services had it kept its foreign-born percentage where it was in 1970.

The effect seems wholly political and wholly through its direct impact on mainstream governing parties. Extensive controls for the impact of international migration on the socio-demographic drivers of welfare demand reduce the measured impact of immigration hardly at all. And although immigration is powerfully implicated in the rise of parties of the New Right, these parties seem to contribute no further pressure on governments to restrain spending growth. In the sense, the New Right parties may be epiphenomenal, products of the same forces that move their political rivals directly.

How seriously should we take these propositions? It is an awkward fact that the biggest apparent effect of immigration is in the estimation with the weakest basis: data from two time points in 18 countries. It does seem appropriate that estimated cumulative impact is greater for an implicitly low-frequency estimation than for very high-frequency - annual at the extreme-modelling. But we do feel diffident about the point estimate in our simple cross-sectional estimation. Our anxiety is only increased by that estimate's vulnerability to inclusion or exclusion of particular cases. Of the cases we include, the USA and the Netherlands carry a heavy burden. If we tell single-country stories, the USA provides an internally consistent one that requires no reference to external

${ }^{18}$ The effect of population under 16 is particularly important given the hypothesis that migration increases social spending by altering the demographic profile of a country. Indeed, our data indicate a positive relationship between changes in migrant stock and changes in the percent of population under 16. (See bivariate correlations in the appendix.) Consequently, while the direct effect of changes in migrant stock is clearly negative, the same changes should also push social spending upwards by increasing the population under 16. The effect should be very slight, however. While changes in population under 16 have a considerable effect on social spending, migration accounts for a very small proportion of this demographic change. 
migratory pressure. Gilens (1999) argues that Americans have become more resistant to welfare, in particular to programs for the poor, as welfare policy has come to be increasingly racialized in its media presentations. The racial focus is mainly on African Americans. But we also know that immigrants also figure in that country's discourse. And we can supply no obvious purely domestic story to cover the Netherlands case. An implication of the US and Netherlands role, however, is that modest increments in the foreign-born share carry much less proportionate charge than big ones. ${ }^{19}$ The case we exclude, Switzerland, is difficult to discuss because of idiosyncrasies in measurement of the scale and scope of its welfare state. If we are forced to include it, then the immigration-welfare spending relationship disappears.

What do the propositions imply? They do seem to vindicate Miller's (1995) worries about threats to the national basis of the welfare state. Obviously, we cannot replicate the steps in his argument with data as highly aggregated and as lacking in direct indicators of voter sentiment as ours are. But suppositionally the evidence points in Miller's direction. International migration will continue to be a fact of life, not least because of declining replacement rates for industrial work forces. And the evidence does not buttress a case against multicultural policies as they actually tend to operate (Banting and Kymlicka 2003). The need to incorporate immigrants into national fabrics will be as pressing as ever, and the evidence suggests that multicultural policies help break down barriers - they do not in fact ghettoize newcomers. The attitudinal problem is more among natives than newcomers and reflects more the apprehension of cultural threat than the fact of threat. But those apprehensions, combined with often realistic appraisals of cost and benefit, ${ }^{20}$ mean that the human component of globalization may represent a constraint on the expansion of welfare states that seemed fully consolidated two decades ago.

19 Although the estimated impact of the average increase in the foreign-born percentage hardly seems trivial.

${ }^{20}$ Certainly, it is natural to wonder if the pattern Soroka et al 2002 observe for Canada-little or no relation between exposure to "new Canadians" and opposition to the welfare state-reflects that country's relative success in "cherry-picking" immigrants who draw on the welfare state less than natives do. 


\section{Appendix A. Data Sources and Descriptives}

Datasets for the 28-year changes model and the 2 to 5-year models were derived from the yearly TSCS dataset. Accordingly, variables are described below as they were created for the yearly TSCS analysis. As described in the text, these variables were collapsed into 2-, 3-, 4-, and 5-year averages for models in Table 4. For results in Table 2, spending and migrant stock variables are measured as the total change from 1970 to 1998; all other variables are the mean for this period.

\section{Variables}

Spending: Social Welfare Spending as a proportion of GDP. Data for 1980-2000 are from the OECD Social Expenditures (SOCX) database. Data for 1960-1980 are from the appendix in OECD, Social expenditure, 1960-1990: Problems of growth and control (OECD, 1985). The means by which these data were merged is described in the text. Data were missing for Austria (1981-4;1986-9) and Norway (1981-4;1986-7), and so are interpolated for these years. The final series are available from 1960-1998, without gaps, for all countries. ${ }^{21}$

Migrant Stock: Migrant Stock as a proportion of the total population, based on UN estimates, as described in the text. The resulting series are available from 1965 to 2000 for all countries.

Population under 16: Population over 64 as a proportion of the total population. Data are from OECD Health Data 2001. Available from 1960 to 1999 for all countries except Italy (19801999).

Population over 64: Population over 64 as a proportion of the total population. Data are from OECD Health Data 2001. Available from 1960 to 1999 for all countries except Italy (19801999).

Female Labour Force: Female labour force as a percentage of the total female population. Data are from OECD Labour Statistics and OECD Health Data 2001. There are some individual years before 1980 for which data are missing; for the final series, these values are interpolated using linear interpolation. Data begin between 1960 and 1964 for all countries except Netherlands (1971).

Total Union Density: Total union membership (less self-employed) weighted by the total dependent labour force. Data are from Miriam Golden, Peter Lange, and Michael Wallerstein (2002) "Union Centralization among Advanced Industrial Societies: An Empirical Study." Dataset available at http://www.shelley.polisci.ucla.edu/data. Version dated September 19, 2002.

21 The two databases have slightly different expenditure definitions, although both include expenditures on education, health, pensions, unemployment, and "other" social welfare programs. Values for 1980 are the same in the two databases for some countries, and slightly different for others. Accordingly, the complete 1960-2000 series were created as follows: Data from 1980-2000 are from the new database. Data for 1979 are estimated by taking the \% difference from 1980 to 1979 in the old database, and applying this same \% difference to derive the 1979 value from the 1980 value in the new database. This is done repeatedly, back to 1960 , so that pre-1980 values in the final series reflect the same $\%$ changes as in the old database, post-1980 values are identical to those in the new database, and there is no artificial punctuation in 1980. This is a relatively common method of merging expenditure series, used by both HM Treasury (UK) and Statistics Canada, for instance. The other possible source of primary data on social expenditures is from the ILO. These ILO data have the advantage of consistency from the 1960s to 1993 , but are no longer being updated. 
Unemployment Rate: Unemployment Rate. Data are from OECD Labour Statistics. Data available from 1960-1998 or 1999 for all countries except Italy (1970-1999), Japan (1962-1999), and Switzerland (1991-1999).

GDP per capita: Gross Domestic Product per capita, in constant US dollars. Data are from OECD Health Data 2001. Data available from 1960 to 2000 for all countries except Denmark (1966-2000).

CPI: $12-$ month \% change in the Consumer Price Index. Data are from IMF Statistics (available at http://www.imf.org). Available from 1960 to 2001 for all countries.

Left party seats: Left governing party seats as a proportion of all legislative seats. This variable is drawn from Duane Swank's Comparative Parties Data Set, available online at http://www.marquette.edu/polisci/Swank.htm. Available from 1960 to 2000 for all countries.

ChristDem party seats: Christian Democratic governing party seats as a proportion of all legislative seats. Same source as above. Available from 1960 to 2000 for all countries.

RW votes: Right Wing Populist votes as a proportion of all party votes. Same source as above. Available from 1960 to 2000 for all countries.

\section{Descriptives}

TSCS analyses are based on data with no gaps, beginning in the first year and ending in the last year as listed below.

[Table A1 about here]

[Table A2 about here] 


\section{References}

Alesina, Alberto, Edward Glaeser and Bruce Sacerdote 2001. "Why Doesn't the United States Have a European-Style Welfare State," Brookings Papers on Economic Activity, Vol. 2:.187277.

Alesina, Alberto, Reza Baquir and William Easterly 2001. "Public Goods and Ethnic Divisions," NBER Working Paper 6009.

Banting, Keith 1999. "Social Citizenship and the Multicultural Welfare State," in Alan Cairns, John Courtney, Peter MacKinnon, Hans Michelmann and David Smith, editors, Citizenship, Diversity and Pluralism: Canadian and Comparative Perspectives. Montreal: McGill-Queen's University Press.

Banting, Keith and Will Kymlicka 2003. "Do Multiculturalism Policies Erode the Welfare State?" Paper presented to the Colloquium Franqui 2003, Cultural Diversities versus Economic Solidarity. Brussels.

Barry, Brian 2001. Culture and Equality: An Egalitarian Critique of Multiculturalism. Cambridge: Polity Press.

Boeri, Tito, Gordon Hanson and Barry McCormick 2002. Editors. Immigration Policy and the Welfare System. Oxford: Oxford University Press.

Borjas, George 1994. "The Economics of Immigration," Journal of Economic Literature, XXXII (4): 1667-1717.

1999. Heaven's Door: Immigration Policy and the American Economy. Princeton, N.J.: Princeton University Press.

Bowles, Samuel, Christina Fong and Herbert Gintis 2001, "Reciprocity and the Welfare State," Ms.

Easterly, William 2001a. "Can Institutions Resolve Ethnic Conflict?" Economic Development and Cultural Change, Vol. 49/4: 687-706.

2001b. The Elusive Quest for Economic Development: Economists'Adventures and Misadventures in the Tropics. MIT Press, Cambridge, MA.

Easterly, William and Ross Levine 1997. "Africa's Growth Tragedy: Policies and Ethnic Divisions", Quarterly Journal of Economics, Vol. 112: 1203-1250.

Economist 2003. "Special Report: Europe's Minorities," May 10: 22-24.

Esping-Anderson, Gosta 1985. Politics Against Markets: The Social Democratic Road to Power. Princeton, N.J.: Princeton University Press.

2002. Why We Need a New Welfare State. Oxford: Oxford University Press.

Garrett, Geoffrey 1998. "Global Markets and National Politics: Collision Course or Virtuous Circle," International Organization, 52: 787-824.

Gilens, Martin 1999. Why Americans Hate Welfare: Race, Media, and the Politics of Antipoverty Policy. Chicago: University of Chicago Press.

Gitlin, Todd 1995. The Twilight of Common Dreams: Why America is Wracked by Culture Wars. ....: Metropolitan Books.

Grafton, Quentin, Stephen Knowles and Dorian Owen 2002. "Social Divergence and Productivity: Making a Connection," in Andrew Sharpe, France St-Hilaire and Keith Banting, eds., The Review of Economic Performance and Social Progress: Towards A Social Understanding of Productivity (Institute for Research in Public Policy, Montreal).

Hall, Peter and David Soskice 2001. Editors. Varieties of Capitalism: The Institutional Foundations of Comparative Advantage. Oxford: Oxford University Press. 
Hero, Rodney and Caroline Tolbert 1996. "A racial/ethnic diversity interpretation of politics and policy in the states of the US," American Journal of Political Science, 840: 851-871.

Hicks, Alexander 1999. Social Democracy and Welfare Capitalism. Ithaca: Cornell Universty Press.

Huber, Evelyne and John Stephens, 2001. Development and Crisis of the Welfare State: Parties and Policies in Global Markets. Chicago: University of Chicago Press.

James, Estelle 1987. "The public/private division of responsibility for education in international comparison," Economics of Education Review, Vol. 6/1: 1-14.

1993. "Why do different countries chose a different public/private mix of education services?" Journal of Human Resources, vol. 28/3: 531-92.

Joppke, Christian 1999. Immigration and the Nation-State: The United States, Germany, and Great Britain. Oxford: Oxford University Press.

Kitschelt, Herbert 1995. The Radical Right in Western Europe: A Comparative Analysis. Ann Arbor: University of Michigan Press.

Kitschelt, Herbert, Peter Lange, Geoffrey Marks and John Stephens. 1999. Continuity and Change in Contemporary Capitalism. Cambridge: Cambridge University Press.

Korpi, Walter 1983. The Democratic Class Struggle. Boston: Routledge and Kegan Paul.

Miller, David 1995. On Nationality. Oxford: Oxford University Press.

Nettle, D. 2000. "Linguistic Fragmentation and the Wealth of Nations," Economic Development and Cultural Change, Vol. 49: 335-348.

OECD 1997. Trends in International Migration: Annual Report 1996. Paris.

Plotnick, Robert and Richard Winters 1985. "A Politico-Economic Theory of Income Redistribution," American Political Science Review, 79: 458-73.

Reich, Robert 1991. The Work of Nations: Preparing Ourselves for $21^{\text {st }}$ Century Capitalism. New York: Random House.

Rodrik, Dani 2002. "Final Remarks," in Tito Boeri, Gordon Hanson and Barry McCormick, editors, Immigration Policy and the Welfare System. Oxford: Oxford University Press.

Sassen, Saskia 1998. "The de facto Transnationalizing of Immigration Policy," in Christian Joppke, editor, Challenge to the Nation State: Immigration in Western Europe and the United States. Oxford: Oxford University Press.

Soroka, Stuart, Richard Johnston and Keith Banting 2002. "Ethnicity, Trust and the Welfare State," Paper presented to the Canadian Political Science Association Meetings, Toronto.

Soysal, Yasemin 1994. Limits of Citizenship. Chicago: University of Chicago Press.

Steinmo, Sven 2003. "Bucking the Trend? The Welfare State and the Global Economy: The Swedish Case Up Close," New Political Economy, 8 (1): 31-48.

Stephens, John 1979. The Transition from Capitalism to Socialism. Urbana: University of Illinois Press.

Swank, Duane 2002. Global Capital, Political Institutions and Policy Change in Developed Welfare States. Cambridge: Cambridge University Press.

Swank, Duane and Hans-Georg Betz forthcoming: "Globalization, the Welfare State, and RightWing Populism in Western Europe," Socio-Economic Review, forthcoming.

Wlezien, Christopher 1996. "Dynamics of Representation: The Case of U.S. Spending on Defence," British Journal of Political Science, 26:81-103.

Wlezien, Christopher and Stuart Soroka 2003. "Measures and Models of Budgetary Policy," Policy Studies Journal, 31: 273-286.

Wolfe, Alan and Jyette Klausen 1997. "Identity Politics and the Welfare State," Social Philosophy and Policy, 14(2): 213-55. 
Table 1. Levels of Social Welfare Spending and Migrant Stock, 1970 and 1998

\begin{tabular}{lccccc}
\hline \hline \multirow{2}{*}{ Country } & \multicolumn{2}{c}{$\begin{array}{c}\text { Social Wefare Spending, } \\
\text { \% of GDP }\end{array}$} & & \multicolumn{2}{c}{$\begin{array}{c}\text { Migrant Stock, } \\
\% \text { of Population }\end{array}$} \\
\cline { 2 - 3 } \cline { 5 - 6 } & 1970 & 1998 & & 1970 & 1998 \\
\hline AUL & 6.5 & 17.8 & & 18.7 & 24.3 \\
AUT & 18.9 & 26.8 & & 2.3 & 8.7 \\
BEL & 15.3 & 24.5 & & 6.7 & 8.7 \\
CAN & 10.5 & 18.0 & & 15.3 & 18.2 \\
DEN & 20.8 & 29.8 & & 2.4 & 5.4 \\
FIN & 13.1 & 26.5 & & 0.7 & 2.3 \\
FRA & 15.6 & 28.8 & & 9.8 & 10.6 \\
FRG & 15.4 & 27.3 & & 3.5 & 8.4 \\
GRE & 9.4 & 22.7 & & 1.1 & 4.7 \\
IRE & 10.5 & 15.8 & & 4.2 & 8.4 \\
ITA & 14.7 & 25.1 & & 1.7 & 2.8 \\
JPN & 4.8 & 14.7 & & 0.6 & 1.2 \\
NET & 21.6 & 23.9 & & 2.7 & 9.5 \\
NOR & 14.3 & 27.0 & & 2.3 & 6.2 \\
NZL & 11.6 & 21.0 & & 15.2 & 21.1 \\
SWE & 18.7 & 31.0 & & 6.0 & 10.8 \\
SWZ & 9.3 & 28.3 & & 14.6 & 23.3 \\
UKM & 14.6 & 24.7 & & 5.0 & 6.7 \\
USA & 10.2 & 14.6 & 5.2 & 11.5 \\
\hline Average & 13.5 & 23.6 & 6.2 & 10.1 \\
\hline \hline
\end{tabular}

Figure 1. Changes in Migrant Stock and Social Welfare Spending

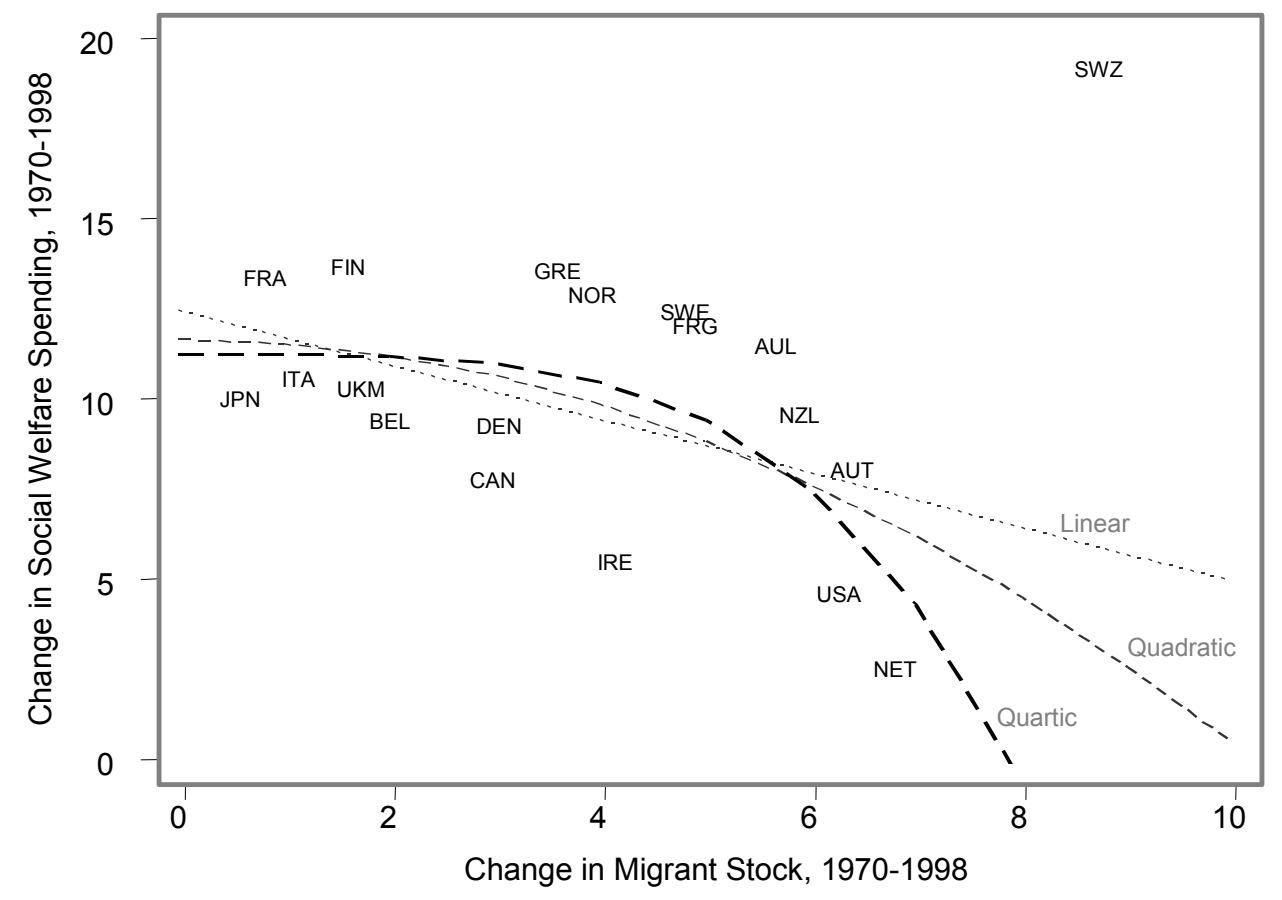


Table 2. Modelling changes in social spending, 1970-1998

\begin{tabular}{|c|c|c|c|c|c|c|}
\hline \multirow[t]{2}{*}{$\begin{array}{l}\text { Independent } \\
\text { Variables }\end{array}$} & \multicolumn{6}{|c|}{$\begin{array}{c}\text { Dependent Variable: } \\
\text { Percentage Point Change in Social Welfare Spending, as a \% of GDP }, 1970-98\end{array}$} \\
\hline & Model 1 & Model 2 & Model 3 & Model 1 & Model 2 & Model 3 \\
\hline$\Delta$ Migrant stock & $\begin{array}{l}-.724^{*} \\
(.359)\end{array}$ & $\begin{array}{l}-.721 \\
(.464)\end{array}$ & $\begin{array}{r}-.724^{* * *} \\
(.232)\end{array}$ & - & - & $\longrightarrow$ \\
\hline$\Delta$ Migrant stock ${ }^{2}$ & - & - & - & $\begin{array}{r}-.109^{* *} \\
(.046)\end{array}$ & $\begin{array}{r}-.129 \\
(.067)\end{array}$ & $\begin{array}{r}-.104^{* * *} \\
(.030)\end{array}$ \\
\hline Social Spending ('70) & $\begin{array}{r}-.040 \\
(.160)\end{array}$ & $\begin{array}{r}-.336 \\
(.248)\end{array}$ & $\begin{array}{r}-.411^{* * *} \\
(.127)\end{array}$ & $\begin{array}{r}-.031 \\
(.154)\end{array}$ & $\begin{array}{r}-.228 \\
(.256)\end{array}$ & $\begin{array}{r}-.377^{* *} \\
(.125)\end{array}$ \\
\hline Left Seats & - & $\begin{array}{l}.166^{*} \\
(.071)\end{array}$ & $\begin{array}{r}.155^{* * *} \\
(.040)\end{array}$ & - & $\begin{array}{l}.180^{* *} \\
(.068)\end{array}$ & $\begin{array}{r}.156^{* * *} \\
(.037)\end{array}$ \\
\hline ChristDem Seats & - & $\begin{array}{r}-.008 \\
(.073)\end{array}$ & - & - & $\begin{array}{r}.008 \\
(.070)\end{array}$ & 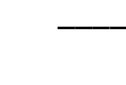 \\
\hline RW Votes & - & $\begin{array}{r}-.096 \\
(.237)\end{array}$ & - & $\longrightarrow$ & $\begin{array}{r}-.160 \\
(.232)\end{array}$ & $\longrightarrow$ \\
\hline Unemployment & $\longrightarrow$ & $\begin{array}{r}.102 \\
(.826)\end{array}$ & - & - & $\begin{array}{r}-.302 \\
(.865)\end{array}$ & $\longrightarrow$ \\
\hline Inflation & 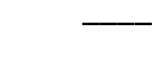 & $\begin{array}{r}.186 \\
(.364)\end{array}$ & - & 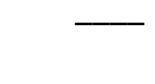 & $\begin{array}{r}.248 \\
(.347)\end{array}$ & 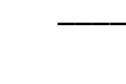 \\
\hline GDP per capita & $\longrightarrow$ & $\begin{array}{r}.112 \\
(.538)\end{array}$ & - & - & $\begin{array}{r}.308 \\
(.543)\end{array}$ & $\longrightarrow$ \\
\hline Female Labour Force & - & $\begin{array}{r}.095 \\
(.092)\end{array}$ & $\begin{array}{l}.102^{*} \\
(.052)\end{array}$ & - & $\begin{array}{r}.085 \\
(.087)\end{array}$ & $\begin{array}{l}.100^{*} \\
(.049)\end{array}$ \\
\hline Population $<16$ & $\longrightarrow$ & $\begin{array}{r}-.119 \\
(.436)\end{array}$ & - & - & $\begin{array}{r}-.047 \\
(.412)\end{array}$ & 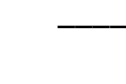 \\
\hline Population $>64$ & $\ldots$ & $\begin{array}{r}.523 \\
(.563)\end{array}$ & $\begin{array}{l}.703^{* *} \\
(.320)\end{array}$ & - & $\begin{array}{r}.276 \\
(.569)\end{array}$ & $\begin{array}{l}.605^{\star} \\
(.316)\end{array}$ \\
\hline Constant & $\begin{array}{r}12.846^{* * *} \\
(2.428)\end{array}$ & $\begin{array}{r}3.403 \\
(17.338)\end{array}$ & $\begin{array}{r}2.086 \\
(4.133)\end{array}$ & $\begin{array}{r}11.976^{* * *} \\
(2.207)\end{array}$ & $\begin{array}{r}1.697 \\
(16.200)\end{array}$ & $\begin{array}{r}2.113 \\
(3.892)\end{array}$ \\
\hline $\begin{array}{l}\text { Observations } \\
\text { R-squared }\end{array}$ & $\begin{array}{r}18 \\
.231\end{array}$ & $\begin{array}{r}18 \\
.841\end{array}$ & $\begin{array}{r}18 \\
.820\end{array}$ & $\begin{array}{r}18 \\
.289\end{array}$ & $\begin{array}{r}18 \\
.862\end{array}$ & $\begin{array}{r}18 \\
.836 \\
\end{array}$ \\
\hline
\end{tabular}

Cells contain OLS regression coefficients with standard errors in parentheses.

${ }^{* * *} p<.01 ;{ }^{* *} p<.05 ;{ }^{*} p<.10$. 
Table 3. Modelling changes in social spending, basic TSCS models

\begin{tabular}{|c|c|c|c|c|c|}
\hline \multirow[t]{2}{*}{$\begin{array}{l}\text { Independent } \\
\text { Variables }\end{array}$} & \multicolumn{5}{|c|}{$\begin{array}{c}\text { Dependent Variable: Percentage Point Change in } \\
\text { Social Welfare Spending as a \% of GDP }\end{array}$} \\
\hline & 5-year & 4-year & 3-year & 2-year & Yearly \\
\hline$\Delta$ Migrant stock ${ }_{\mathrm{t}}^{2}$ & $\begin{array}{r}-.024^{* * *} \\
(.008)\end{array}$ & $\begin{array}{r}-.022^{* * *} \\
(.008)\end{array}$ & $\begin{array}{r}.023^{* * *} \\
(.007)\end{array}$ & $\begin{array}{r}-.023^{* * *} \\
(.008)\end{array}$ & $\begin{array}{r}-.023^{* * *} \\
(.008)\end{array}$ \\
\hline Spending $\mathrm{t}-1$ & $\begin{array}{r}-.076 \\
(.050)\end{array}$ & $\begin{array}{l}-.067^{*} \\
(.039)\end{array}$ & $\begin{array}{l}-.059^{*} \\
(.031)\end{array}$ & $\begin{array}{l}-.036^{*} \\
(.020)\end{array}$ & $\begin{array}{r}-.018^{* *} \\
(.009)\end{array}$ \\
\hline Constant & $\begin{array}{r}3.506^{* * *} \\
(.903)\end{array}$ & $\begin{array}{r}2.732^{* * *} \\
(.715)\end{array}$ & $\begin{array}{r}2.265^{* * *} \\
(.573)\end{array}$ & $\begin{array}{r}1.469^{\star \star *} \\
(.379)\end{array}$ & $\begin{array}{r}.740^{* * *} \\
(.178)\end{array}$ \\
\hline $\begin{array}{l}\text { Observations } \\
\text { Number of Countries } \\
\text { R-squared }\end{array}$ & $\begin{array}{r}107 \\
18 \\
.116 \\
\end{array}$ & $\begin{array}{r}160 \\
18 \\
.105\end{array}$ & $\begin{array}{r}197 \\
18 \\
.088 \\
\end{array}$ & $\begin{array}{r}303 \\
18 \\
.058 \\
\end{array}$ & $\begin{array}{r}593 \\
18 \\
.029 \\
\end{array}$ \\
\hline
\end{tabular}

Cells contain regression coefficients from a time-series cross-sectional analysis using panel-corrected standard errors (in parentheses).

${ }^{* * *} p<.01 ;{ }^{* *} p<.05 ;{ }^{*} p<.10$. 
Table 4. Modelling changes in social spending, TSCS analysis at various intervals

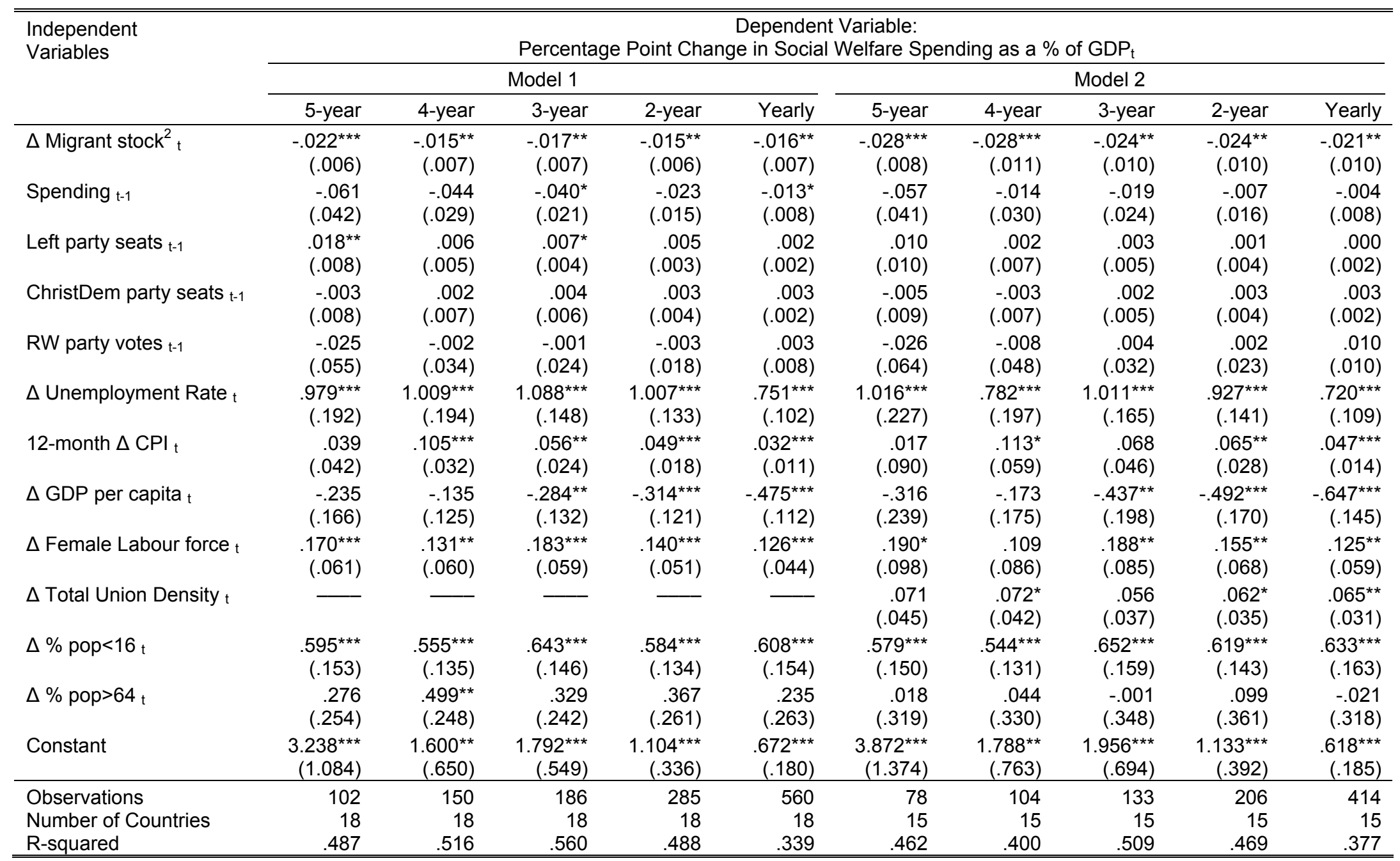

Cells contain regression coefficients from a time-series cross-sectional analysis using panel-corrected standard errors (in parentheses).

${ }^{* * *} p<.01 ;{ }^{* *} p<.05 ;{ }^{*} p<.10$. 
Table A1. Data availability ${ }^{\text {a }}$

\begin{tabular}{lrrrrrrr}
\hline \hline \multirow{2}{*}{ Country } & \multicolumn{3}{c}{ Without Union Density } & & \multicolumn{3}{c}{ With Union Density } \\
\cline { 2 - 3 } \cline { 7 - 8 } & $\mathrm{N}$ (year) & First Year & Last Year & & $\mathrm{N}$ (year) & First Year & Last Year \\
\hline AUL & 34 & 1966 & 1999 & & 24 & 1966 & 1989 \\
AUT & 30 & 1969 & 1998 & & 28 & 1969 & 1996 \\
BEL & 33 & 1966 & 1998 & & 30 & 1966 & 1995 \\
CAN & 34 & 1966 & 1999 & & 34 & 1966 & 1999 \\
DEN & 28 & 1971 & 1998 & & 27 & 1971 & 1997 \\
FIN & 33 & 1966 & 1998 & & 32 & 1966 & 1997 \\
FRA & 33 & 1966 & 1998 & & 30 & 1966 & 1995 \\
FRG & 33 & 1966 & 1998 & & 32 & 1966 & 1997 \\
GRE & 24 & 1975 & 1998 & & & $n$ & \\
IRE & 33 & 1966 & 1998 & & & $n$ & \\
ITA & 18 & 1981 & 1998 & & 17 & 1981 & 1997 \\
JPN & 33 & 1966 & 1998 & & 16 & 1966 & 1981 \\
NET & 27 & 1972 & 1998 & & 26 & 1972 & 1997 \\
NOR & 33 & 1966 & 1998 & & 32 & 1966 & 1997 \\
NZL & 34 & 1966 & 1999 & & & $n$ & \\
SWE & 33 & 1966 & 1998 & & 32 & 1966 & 1997 \\
UKM & 33 & 1966 & 1998 & & 30 & 1966 & 1995 \\
USA & 34 & 1966 & 1999 & & 24 & 1966 & 1989 \\
\hline \hline
\end{tabular}

${ }^{a}$ TSCS analyses are based on data with no gaps, beginning in the first year and ending in the last year as listed above. 
Table A2. Bivariate correlations ${ }^{\mathrm{b}}$

\begin{tabular}{|c|c|c|c|c|c|c|c|c|c|c|c|c|}
\hline & Variables & 1 & 2 & 3 & 4 & 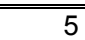 & 6 & 7 & 8 & 9 & 10 & 11 \\
\hline \multirow[t]{2}{*}{1} & $\Delta$ Social spending $_{\mathrm{t}}$ & 1.000 & & & & & & & & & & \\
\hline & & $(672)$ & & & & & & & & & & \\
\hline \multirow[t]{2}{*}{2} & $\Delta$ Migrant stock ${ }_{\mathrm{t}-1}$ & -.075 & 1.000 & & & & & & & & & \\
\hline & & $\begin{array}{r}.067 \\
(593)\end{array}$ & $(630)$ & & & & & & & & & \\
\hline \multirow[t]{2}{*}{3} & Left Seats ${ }_{t-1}$ & .062 & .041 & 1.000 & & & & & & & & \\
\hline & & $\begin{array}{r}.114 \\
(660)\end{array}$ & $\begin{array}{r}.306 \\
(621)\end{array}$ & (723) & & & & & & & & \\
\hline \multirow[t]{2}{*}{4} & ChristDem Seats $_{t-1}$ & .018 & .044 & -.086 & 1.000 & & & & & & & \\
\hline & & $\begin{array}{r}.653 \\
(660)\end{array}$ & $\begin{array}{r}.272 \\
(621)\end{array}$ & $\begin{array}{r}.020 \\
(723)\end{array}$ & (723) & & & & & & & \\
\hline \multirow[t]{2}{*}{5} & RW Votes ${ }_{t-1}$ & -.075 & .199 & .140 & .025 & 1.000 & & & & & & \\
\hline & & $\begin{array}{r}.053 \\
(660)\end{array}$ & $\begin{array}{r}.000 \\
(621)\end{array}$ & $\begin{array}{r}.000 \\
(723)\end{array}$ & $\begin{array}{r}.497 \\
(723)\end{array}$ & (723) & & & & & & \\
\hline \multirow[t]{2}{*}{6} & $\Delta$ Unemployment Rate $_{\mathrm{t}}$ & .445 & -.022 & .011 & -.008 & .002 & 1.000 & & & & & \\
\hline & & $\begin{array}{r}.000 \\
(660)\end{array}$ & $\begin{array}{r}.582 \\
(604)\end{array}$ & $\begin{array}{r}.776 \\
(673)\end{array}$ & $\begin{array}{r}.836 \\
(673)\end{array}$ & $\begin{array}{r}.951 \\
(673)\end{array}$ & (687) & & & & & \\
\hline \multirow[t]{2}{*}{7} & 12-month $\Delta \mathrm{CPI}_{\mathrm{t}}$ & .263 & -.170 & .072 & -.139 & -.194 & .251 & 1.000 & & & & \\
\hline & & $\begin{array}{r}.000 \\
(672)\end{array}$ & $\begin{array}{r}.000 \\
(630)\end{array}$ & $\begin{array}{r}.052 \\
(723)\end{array}$ & $\begin{array}{r}.000 \\
(723)\end{array}$ & $\begin{array}{r}.000 \\
(723)\end{array}$ & $\begin{array}{r}.000 \\
(687)\end{array}$ & $(756)$ & & & & \\
\hline \multirow[t]{2}{*}{8} & GDP per capita & -.357 & .054 & .032 & -.091 & .250 & -.290 & -.117 & 1.000 & & & \\
\hline & & $\begin{array}{r}.000 \\
(672)\end{array}$ & $\begin{array}{r}.177 \\
(629)\end{array}$ & $\begin{array}{r}.399 \\
(700)\end{array}$ & $\begin{array}{r}.016 \\
(700)\end{array}$ & $\begin{array}{r}.000 \\
(700)\end{array}$ & $\begin{array}{r}.000 \\
(681)\end{array}$ & $\begin{array}{r}.002 \\
(714)\end{array}$ & (714) & & & \\
\hline \multirow[t]{2}{*}{9} & $\Delta$ Female Labour force $_{t}$ & .037 & -.051 & .028 & -.077 & -.017 & -.072 & .144 & .186 & 1.000 & & \\
\hline & & $\begin{array}{r}.352 \\
(645)\end{array}$ & $\begin{array}{r}.209 \\
(610)\end{array}$ & $\begin{array}{r}.474 \\
(668)\end{array}$ & $\begin{array}{r}.048 \\
(668)\end{array}$ & $\begin{array}{r}.671 \\
(668)\end{array}$ & $\begin{array}{r}.065 \\
(659)\end{array}$ & $\begin{array}{r}.000 \\
(681)\end{array}$ & $\begin{array}{r}.000 \\
(675)\end{array}$ & (681) & & \\
\hline \multirow[t]{2}{*}{10} & $\Delta$ Total Union Density $\mathrm{t}_{\mathrm{t}}$ & .130 & -.157 & .158 & -.010 & -.033 & -.015 & .130 & -.138 & -.062 & 1.000 & \\
\hline & & $\begin{array}{r}.004 \\
(504)\end{array}$ & $\begin{array}{r}.001 \\
(444)\end{array}$ & $\begin{array}{r}.000 \\
(534)\end{array}$ & $\begin{array}{r}.814 \\
(534)\end{array}$ & $\begin{array}{r}.444 \\
(534)\end{array}$ & $\begin{array}{r}.745 \\
(506)\end{array}$ & $\begin{array}{r}.003 \\
(534)\end{array}$ & $\begin{array}{r}.002 \\
(513)\end{array}$ & $\begin{array}{r}.168 \\
(493)\end{array}$ & $(534)$ & \\
\hline \multirow[t]{2}{*}{11} & $\Delta \%$ pop $<16_{t}$ & $\begin{array}{r}.027 \\
.027\end{array}$ & $\begin{array}{r}.264 \\
\end{array}$ & $\begin{array}{r}1044 \\
.023\end{array}$ & .217 & . 138 & -.089 & -.255 & -.110 & -.223 & -.083 & 1.000 \\
\hline & & $\begin{array}{r}.493 \\
(652)\end{array}$ & $\begin{array}{r}.000 \\
(597)\end{array}$ & $\begin{array}{r}.557 \\
(668)\end{array}$ & $\begin{array}{r}.000 \\
(668)\end{array}$ & $\begin{array}{r}.000 \\
(668)\end{array}$ & $\begin{array}{r}.021 \\
(677)\end{array}$ & $\begin{array}{r}.000 \\
(682)\end{array}$ & $\begin{array}{r}.004 \\
(676)\end{array}$ & $\begin{array}{r}.000 \\
(653)\end{array}$ & $\begin{array}{r}.064 \\
(498)\end{array}$ & (682) \\
\hline \multirow[t]{2}{*}{12} & $\Delta \%$ pop $>64_{t}$ & $\begin{array}{r}1000 \\
.009\end{array}$ & -.166 & $\begin{array}{r}1000) \\
.063\end{array}$ & $\begin{array}{l}1000) \\
.058\end{array}$ & $\begin{array}{l}-000) \\
-.070\end{array}$ & $\begin{array}{l}-.024 \\
-.024\end{array}$ & $\begin{array}{r}1002) \\
.008\end{array}$ & -.031 & $\begin{array}{l}-.037 \\
-.037\end{array}$ & $\begin{array}{l}1450) \\
.184\end{array}$ & $\begin{array}{l}(002) \\
-.219\end{array}$ \\
\hline & & $\begin{array}{r}.826 \\
(652)\end{array}$ & $\begin{array}{r}.000 \\
(597)\end{array}$ & $\begin{array}{r}.102 \\
(668)\end{array}$ & $\begin{array}{r}.133 \\
(668)\end{array}$ & .073 & .538 & $\begin{array}{r}.826 \\
(682)\end{array}$ & $\begin{array}{r}.421 \\
.676)\end{array}$ & $\begin{array}{r}.341 \\
\end{array}$ & $\begin{array}{r}.000 \\
(498)\end{array}$ & $\begin{array}{r}.000 \\
(682)\end{array}$ \\
\hline
\end{tabular}

Cells contain pairwise bivariate correlation coefficients using all available cases from 1960-2000. Significance levels are in italics; the number of observations is in parentheses. All correlations significant at $p<.05$ are in bold.

${ }^{\mathrm{b}}$ To check for collinearity in the models presented in Table 3, these correlations were also generated using (a) only cases included in Model 1 and (b) only cases included in Model 2. Results do not change dramatically.) 